\title{
ISOLASI DAN IDENTIFIKASI MOLEKULAR BAKTERI TOLERAN URANIUM YANG BERPOTENSI DALAM BIOPRESIPITASI URANIUM
}

\section{ISOLATION AND MOLECULAR IDENTIFICATION OF URANIUM TOLERANT BACTERIA POTENTIAL FOR URANIUM BIOPRECIPITATION}

\author{
A. Bernadetta Octavia', B. Triwibowo Yuwono², dan C. Agus Taftazani ${ }^{3}$ \\ 1 Jurdik Biologi - FMIPA UNY, Karang Malang Sleman Yogyakarta, 55281 \\ ${ }^{2}$ Fakultas Pertanian - Universitas Gadjah Mada Yogyakarta, Jl. Flora Bulaksumur Sleman Yogyakarta, 55281 \\ ${ }^{3}$ Pusat Sains dan Teknologi Akselerator - Badan Tenaga Nuklir Nasional, Jl. Babarsari Sleman Yogyakarta, 55281 \\ dettac_via@yahoo.com
}

Diterima 16 November 2017, diterima dalam bentuk perbaikan 17 Januari 2018, disetujui 12 Maret 2018

\begin{abstract}
ABSTRAK
ISOLASI DAN IDENTIFIKASI MOLEKULAR BAKTERI TOLERAN URANIUM YANG BERPOTENSI DALAM BIOPRESIPITASI URANIUM. Penelitian mengenai bakteri toleran uranium yang berpotensi dalam biopresipitasi uranium telah dilakukan. Skrining dilakukan untuk menetapkan bakteri yang paling toleran uranium dengan medium TGY cair yang mengandung larutan uranium dengan konsentrasi bertingkat 0,4 $\mathrm{mM}$; 0,8 mM; $1 \mathrm{mM}$; dan $2 \mathrm{mM}$ terhadap isolat bakteri hasil isolasi dari limbah radioaktif cair aktivitas rendah fase organik dan fase air yang dimiliki oleh PSTA BATAN Yogyakarta. Dari hasil skrining awal (preliminary screening) ini diperoleh 51 isolat bakteri toleran uranium. Setelah dilakukan karakterisasi yang meliputi pengecatan Gram, pengamatan bentuk sel dan morfologi koloni serta penghitungan kinetika pertumbuhan dan dikombinasikan dengan teknik rep-PCR maka diperoleh 26 klaster dari 51 isolat bakteri pada tingkat keserupaan (similarity) 83\%. Selanjutnya dari tiap klaster dipilih satu isolat dengan laju pertumbuhan spesifik $(\mu)$ tertinggi. Dengan demikian didapatkan 26 isolat bakteri toleran uranium yang diuji selanjutnya sebagai bakteri polifosfat. Untuk mendapatkan bakteri polifosfat maka isolat bakteri ini ditumbuhkan dalam medium agar plate yang tidak mengandung $P$ dan diinkubasikan selama 5 hari pada suhu ruang untuk diamati daya hidup (viability) dan perkembangannya. Berdasarkan hasil seleksi ini diperoleh 7 isolat bakteri polifosfat yang mampu tumbuh dan berkembang dengan menggunakan cadangan polifosfat di dalam selnya sebagai sumber energi dan berpotensi dalam biopresipitasi uranium. Bakteri polifosfat ini diberi kode : A-14, A-25, A66, A-67 I, 0-21, 0-27 dan 0-29. Selain karakterisasi dilakukan pula identifikasi molekular berdasarkan urutan nukleotida 16S rDNA terhadap 7 isolat bakteri polifosfat. Hasil analisis hubungan filogenetik 7 isolat bakteri polifosfat menggunakan bakteri acuan Bacillus cereus ATCC 14579 dan Acinetobacter radioresisten DSM 6976 dengan melihat nilai keserupaan dan perbedaan nukleotida maka dapat ditetapkan bahwa isolat bakteri dengan kode A-35, A-14, A-66, 0-27, 0-21, dan 0-29 memiliki kemiripan dengan Bacillus cereus sedangkan isolat bakteri dengan kode A-67 I memiliki kemiripan dengan Acinetobacter radioresisten.
\end{abstract}

Kata kunci: Uranium, identifikasimolekuler, bakteripolifosfat

\section{ABSTRACT}

ISOLATION AND MOLECULAR IDENTIFICATION OF URANIUM TOLERANT BACTERIA POTENTIAL FOR URANIUM BIOPRECIPITATION. A study on uranium tolerant bacteria and their potential in uranium bioprecipitation has been conducted. A pool of bacterial isolates obtained from low organic and liquid phase of radioactive waste were screened based on their capability to withstand on the uranium in a series of growth media (TGY) containing $0.4 \mathrm{mM} ; 0.8 \mathrm{mM} ; 1.0 \mathrm{mM}$; dan $2.0 \mathrm{mM}$ uranium. Following the screening, a total of 51 isolates were obtained demonstrating resistance to uranium. Subsequently, a series of characterization protocols were conducted and resulted in 26 clusters of 51 isolates, exhibiting an 80\% similarity. One isolate demonstrating the highest specific growth rate was subsequently selected from each cluster to give 26 uranium tolerant isolates which were used as polyphosphate bacteria. The selection was conducted based on their viability and growth on no phosphate containing media after 5 days. Based on this selection, a total of 7 polyphosphate bacteria were obtained which demonstrated their capability to use the phosphate stored in the cell as the energy source, therefore potential as uranium bioprecipitation. These 7 isolates were further characterized by $16 \mathrm{~S}$ rDNA sequence analysis. The phylogenetic analysis relationships 
using reference bacteria Bacillus cereus ATCC 14579 and Acinetobacter radioresisten DSM 6976 demonstrated that bacterial isolates A-35, A-14, A-66, 0-27 and 0-29 exhibited similarities with Bacillus cereus, whereas bacterial isolateA-67 I shows similarity with Acinetobacter radioresisten.

Keywords: Uranium, molecular identification, polyphosphate bacteria

\section{PENDAHULUAN}

$P$ encemaran logam berat dan radionuklida (misalnya : uranium dan produk-produk peluruhannya) telah sejak lama menjadi fokus utama pemikiran dan penelitian karena berkaitan dengan kesehatan manusia, hewan dan ekosistem [1]. Kontaminasi air tanah, tanah dan sedimen oleh uranium merupakan masalah lingkungan yang nyata di seluruh dunia dan mempunyai kecenderungan meningkat karena pembuangan dan praktek penggunaan yang salah $[2,3,4]$. Sumber kontaminasi uranium dapat berasal dari sumberdaya alami, sebagai contoh batuan fosfat dapat mengandung uranium dalam jumlah yang nyata sehingga erosi tanah-tanah pertanian yang menggunakan pupuk fosfat secara berlebihan dapat menjadi sumber kontaminasi uranium yang dapat mencemari tanah dan air tanah sebagai sumber air minum $[5,6]$. Selain itu sumber kontaminasi uranium yang nyata ialah penambangan uranium. Penambangan uranium dan proses penyiapannya sebagai bahan bakar akan melepaskan ${ }^{238} \mathrm{U},{ }^{234} \mathrm{U}$ dan produk-produk peluruhannya sehingga menaikkan konsentrasi uranium dan radionuklida yang lain di atas konsentrasi yang ada [5]. Hal ini berarti bahwa kontaminasi uranium tidak hanya terjadi di negara-negara yang memiliki fasilitas pembangkit listrik bertenaga nuklir ataupun negara-negara yang mengembangkan senjata nuklir saja.

Manajemen pengolahan limbah uranium merupakan tantangan yang terus-menerus diupayakan perbaikannya. Secara umum metode pengolahan limbah yang mengandung uranium maupun logam berat yang lain dikelompokkan menjadi 3 metode yaitu metode fisikawi, kimiawi dan hayati. Pada umumnya pemilihan metode pengolahan limbah yang paling sesuai tergantung pada beberapa hal yaitu: a) bahaya yang ditimbulkan oleh keberadaan senyawa toksik tersebut terhadap lingkungan, b) karakteristik lokasi terdapatnya limbah, c) konsentrasi serta jenis polutan, d) pertimbangan resiko sebelum, selama dan setelah remediasi, dan e) biaya remediasi [3]. Metode fisikawi/kimiawi sudah diaplikasikan untuk menghilangkan ion-ion logam dari limbah cair tetapi pada umumnya metode-metode ini secara komersial tidak praktis, baik karena biaya operasionalnya yang tinggi maupun kesulitan mengaplikasikannya apabila limbah yang dihasilkan berbentuk padat. Sebagai contoh, penggunaan teknologi konvensional seperti ion exchange, chemical presipitation, reverse osmosis dan evaporation recovery untuk perlakuan terhadap limbah padat seringkali tidak efisien dan sangat mahal $[7,8]$. Oleh karena itu pengembangan strategi remediasi alternatif sangat penting untuk konservasi lingkungan dan kesehatan manusia. Strategi remediasi alternatif yang dikembangkan saat ini adalah bioremediasi, suatu teknologi baru dan menarik dengan pendekatan multidisiplin yang memanfaatkan berbagai sistem biologi untuk mendegradasi/transformasi polutan dalam air dan tanah. Teknologi ini dapat menggunakan tanaman (fitoremediasi), interaksi tanaman-mikrobia (rhizoremediasi), populasi mikrobia untuk menstimulasi populasi mikrobia alami yang dapat tumbuh (biostimulasi), introduksi artifisial populasi mikrobia yang dapat tumbuh (bioaugmentasi), bioakumulasi (menggunakan sel hidup) dan penggunaan biomassa mikrobia yang hidup maupun yang tidak hidup (biosorpsi/biopresipitasi) untuk membersihkan tempat-tempat yang tercemar. Bioremediasi ini sederhana, mudah diaplikasikan untuk area yang luas, ramah lingkungan dan tidak mahal [9].

Di antara proses-proses bioteknologi tersebut biopresipitasi menawarkan pendekatan strategi biosorpsi yang lebih fleksibel karena tidak dibatasi oleh ketersediaan tempat pengikatan logam pada permukaan sel bakteri seperti halnya pada biosorpsi dan juga tidak dibatasi oleh toksisitas logam yang terakumulasi dalam sel [10]. Biopresipitasi logam berat dan radionuklida pada membran sel yang mensekresikan fosfat merupakan metode yang efektif dalam mengurangi volume limbah, dengan demikian juga mengurangi biaya penyimpanan limbah radioaktif berjangka [8]. Strategi biopresipitasi diawali dengan isolasi bakteri spesifik yang mampu melakukan metabolisme polifosfat dan mensekresikan fosfat keluar selnya. Beberapa penelitian telah melaporkan biopresipitasi logam oleh bakteri pada berbagai kondisi lingkungan seperti biopresipitasi uranium dan kadmium di lingkungan asam oleh Citrobacter sp. [11], biopresipitasi uranium pada kisaran pH asam sampai netral oleh 
Bacillus sp., Rahnella sp. [12,13], Pseudomonas sp. [14] dan Salmonella sp. [15]. Biopresipitasi dan biorecovery uranium dalam limbah asam/netral dapat pula dilakukan oleh bakteri hasil rekayasa genetika yang juga bersifat radioresisten, yaitu Deinococcus radiodurans R1 [10]. Kemampuan biopresipitasi bakteri tidak hanya terbatas dalam lingkungan limbah yang asam dan netral, tetapi dalam limbah yang bersifat basa pun dapat diisolasi bakteri Sphingomonas sp. strain BSAR-1 yang mampu melakukan biopresipitasi uranium [16]. Hasil-hasil penelitian tersebut selain membuktikan tentang kemampuan dan peran bakteri dalam proses biopresipitasi uranium, juga telah menjadi inspirasi untuk dilakukannya penelitian serupa dengan memanfaatkan potensi isolat bakteri lokal Indonesia. Oleh karena itu penelitian yang dilakukan ini berfokus pada isolasi bakteri dari limbah radioaktif cair aktivitas rendah di PSTA BATAN Yogyakarta yang selain toleran uranium juga merupakan bakteri polifosfat yang berpotensi dalam biopresipitasi uranium.

\section{METODOLOGI}

Sampel limbah yang mengandung uranium diperoleh dari Pusat Sains dan Teknologi Akselerator (PSTA) BATAN Yogyakarta. Sampel berupa limbah radioaktif cair aktivitas rendah fase air dan fase organik. Sampel limbah ini masing-masing diinokulasikan sebanyak 10\% (v/v) ke dalam medium cair TGY (Tryptone Glucose Yeast Extract) yang mengandung $0,4 \mathrm{mM}$ larutan uranium $\left(\mathrm{UO}_{2}\left(\mathrm{NO}_{3}\right) 2 \cdot 6 \mathrm{H}_{2} \mathrm{O}\right)$. Medium TGY yang telah diinokulasi dengan sampel limbah digojog $160 \mathrm{rpm}$ selama 24 - 48 jam (sampai keruh/ada pertumbuhan), pada suhu ruang $\left(28^{\circ} \mathrm{C}\right)$. Setelah itu dibuat pengenceran $10^{-1}$ sampai $10^{-6}$, dan dari masing-masing pengenceran tersebut ditanam dengan metode tuang permukaan (surface plate) pada media agar TGY yang mengandung 0,4 $\mathrm{mM}$ larutan uranium dan diinkubasikan pada suhu ruang selama $24-48$ jam. Koloni-koloni yang tumbuh terpisah secara acak diambil dan diisolasi serta dimurnikan. Selanjutnya dilakukan skrining bertingkat terhadap semua isolat bakteri toleran uranium $0,4 \mathrm{mM}$ dengan ditumbuhkan dalam medium TGY cair dengan konsentrasi bertingkat 0,8 mM, $1 \mathrm{mM}$ dan $2 \mathrm{mM}$ dengan kriteria penilaian yang digunakan adalah tumbuh dan tidak tumbuh. Melalui skrining awal ini diperoleh sejumlah isolat bakteri yang menunjukkan toleransi terhadap larutan uranium dan yang dipergunakan dalam studi selanjutnya.

Pengecatan Gram dilakukan untuk menegaskan sifat Gram positif atau Gram negatif dari isolat bakteri tersebut. Kinetika pertumbuhan dibuat dengan menumbuhkan isolat bakteri dalam medium cair phoshate uptake [17] kemudian diikuti pertumbuhannya dengan spektrofotometer pada panjang gelombang $600 \mathrm{~nm}$ sehingga diperoleh fase-fase dalam kurva pertumbuhannya dan dihitung kecepatan pertumbuhan spesifik $(\mu)$ untuk masing-masing isolat bakteri tersebut. Tahap karakterisasi selanjutnya adalah melakukan Rep-PCR. Dalam penelitian ini Rep-PCR dilakukan dengan Kit yang diproduksi oleh GE Health care, UK. Rep-PCR diawali dengan isolasi DNA bakteri kemudian dilakukan PCR dengan DNA primer Box Air. DNA primer ini akan berpasangan (komplemen) dengan elemen berulang pada genom DNA bakteri sehingga akan memunculkan profil sidik jari rep-PCR. Selanjutnya berdasarkan pola sidik jari yang diperoleh dilakukan analisis keserupaan untuk klasifikasi dan identifikasi awal isolat bakteri tersebut [18].

Analisis keserupaan profil sidik jari hasil rep-PCR akan menghasilkan pengelompokan isolat bakteri toleran uranium ke dalam beberapa klaster. Setelah itu dari setiap klaster dipilih satu isolat bakteri yang mempunyai nilai $\mu$ tertinggi. Selanjutnya terhadap beberapa bakteri yang terpilih dari setiap klaster dilakukan skrining untuk diketahui kemampuannya sebagai bakteri polifosfat. Skrining kemampuan ini dilakukan dengan menumbuhkan isolat bakteri pada medium agar yang tidak mengandung fosfat [19] dan diinkubasikan selama 5 hari pada suhu kamar. Pertumbuhan diamati dan hanya isolat bakteri yang mampu tumbuh pada medium Free- $P$ yang dipilih menjadi kandidat bakteri polifosfat dan dipelajari lebih lanjut untuk biopresipitasi uranium.

Isolat bakteri polifosfat yang diperoleh selanjutnya diidentifikasi secara molekular dengan menggunakan metode amplifikasi urutan nukleotida gen $16 \mathrm{~S}$ rRNA. Tahapan identifikasi molekular isolat bakteri terpilih yaitu 1) Isolasi DNA isolat bakteri terpilih, 2) Amplifikasi urutan nukleotida gen $16 \mathrm{~S}$ rRNA dengan PCR dan 3) Penentuan urutan nukleotida hasil amplifikasi gen $16 \mathrm{~S}$ rRNA. Isolasi DNA dimulai dengan menumbuhkan isolat bakteri dalam $10 \mathrm{ml}$ media TGY cair pada suhu ruang selama \pm 18 jam, digojog dengan kecepatan $\pm 160 \mathrm{rpm}$ dan selanjutnya dilakukan isolasi DNA dengan menggunakan metode [20] DNA genom bakteri hasil isolasi ini digunakan sebagai DNA template/cetakan untuk amplifikasi gen 16S-rRNA menggunakan Thermocycler Gene 
Cycler (Biorad). Amplifikasi gen 16S-rRNA menggunakan kit Ready To Go PCR Beads (Pharmacia-Biotech), primer universal 16S-rRNA prokaryot, yaitu forward primer 27F (5'-AGA GTT TGA TCC TGG CTC AG-3') dan reverse primer 1492R (5'-TAC GGY TAC CTT GTT ACG ACT T-3') [21]. PCR dilakukan dengan mencampur DNA genom bakteri dengan bahan yang diperlukan untuk reaksi PCR. Program untuk amplifikasi gen 16S rRNA ditampilkan pada Tabel berikut.

Tabel 1. Kondisi reaksi PCR untuk amplifikasi gen 16S-rRNA

\begin{tabular}{llcc}
\hline No & Reaksi & Suhu $\left({ }^{\circ} \mathrm{C}\right)$ & Waktu (menit) \\
\hline 1 & Denaturasi awal & 94 & 5,0 \\
& 30 siklus & & \\
2 & Denaturasi & 94 & 1,0 \\
& Annealing & 72 & 1,0 \\
& Ekstensi & 72 & 1,0 \\
3 & Ekstensi akhir & 72 & 10,0 \\
\hline
\end{tabular}

Hasil amplifikasi gen 16S-rRNA selanjutnya ditentukan urutan nukleotidanya pada perusahaan jasa DNA sequencing PT Genetika Science Indonesia (1 ${ }^{\text {st }}$ BASE Pte.Ltd.), untuk mengetahui susunan basa nukleotida yang menjadi gen 16S-rRNA isolat bakteri terpilih. Sebanyak $40 \mu$ amplikon digunakan untuk penentuan urutan nukleotida. Hasil penentuan urutan nukleotida berupa urutan data asam amino dapat dilihat kualitasnya dengan menggunakan program perangkat lunak DNA Baser dan dilakukan analisis menggunakan BLAST (Basic Local Alignment Search Tool).

\section{HASIL DAN PEMBAHASAN}

\section{Isolasi dan Karakterisasi Isolat Bakteri Toleran Uranium}

Sampel penelitian adalah limbah radioaktif cair aktivitas rendah yang diperoleh dari Pusat Sains dan Teknologi Akselerator (PSTA) BATAN Yogyakarta. Sampel limbah radioaktif yang diambil berupa limbah fase air dan limbah fase organik. Limbah fase air adalah seluruh limbah cair yang berasal dari sisa-sisa hasil penelitian laboratorium di lingkungan BATAN, sedangkan limbah fase organik merupakan limbah pemrosesan bijih uranium menjadi pellet $\mathrm{UO}_{2}$ yang pada beberapa tahap pemrosesannya bijih uranium tersebut diekstraksi dengan TBPkerosen. Diharapkan kedua macam limbah ini dapat mewakili keseluruhan limbah yang dihasilkan oleh PSTA BATAN sehingga isolat bakteri toleran uranium yang diperoleh dapat mewakili limbah yang dihasilkan oleh PSTA BATAN. Berdasarkan atas hasil isolasi dan skrining bertingkat dalam medium TGY yang mengandung uranium mulai dari konsentrasi $0,4 \mathrm{mM} ; 0,8 \mathrm{mM} ; 1 \mathrm{~mm}$ dan $2 \mathrm{mM}$ telah diperoleh bakteri toleran uranium sebanyak 51 isolat bakteri yaitu 29 isolat dari fase air dan 22 isolat dari fase organik (Tabel 2).

Tabel 2. Bakteri toleran uranium dari fase air dan fase organik setelah dilakukan skrining bertingkat konsentrasi uranium.

\begin{tabular}{lcc}
\hline Konsentrasi uranium & Fase air & Fase organik \\
\hline $0,4 \mathrm{mM}$ & 104 & 60 \\
$0,8 \mathrm{mM}$ & 83 & 45 \\
$1 \mathrm{mM}$ & 29 & 24 \\
$2 \mathrm{mM}$ & 29 & 22 \\
\hline
\end{tabular}

Selanjutnya 51 isolat ini ditumbuhkan dalam media pertumbuhan untuk dihitung kinetika pertumbuhan masing-masing isolat, pengecatan Gram, pengamatan bentuk sel dan morfologi koloni. Rangkuman hasil pengamatan ini disajikan pada Tabel 3. 
Tabel 3. Hasil pengamatan morfologi koloni, pengecatan Gram dan kinetika pertumbuhan 51 isolat bakteri toleran uranium

\begin{tabular}{|c|c|c|c|c|c|c|c|}
\hline Gram & No & Isolat & 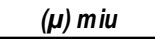 & Surface & Configuration & Margin & Elevation \\
\hline & 1 & A50 & 0.169676977 & Rough & Wrinkled & Wavy (undulate) & Hilly \\
\hline & 2 & 01 & 0.135529415 & Rough & L-form & Wavy (undulate) & Umbonate \\
\hline & 3 & A35 & 0.135078046 & Rough & Round & Entire (smooth) & Umbonate \\
\hline & 4 & A53 & 0.121850442 & Rough & Wrinkled & Lobate & Hilly \\
\hline & 5 & A108 & 0.117837647 & Rough & L-form & Wavy (undulate) & Umbonate \\
\hline & 6 & 023 & 0.114775379 & Rough & Wrinkled & Lobate & Hilly \\
\hline & 7 & A62 & 0.112190018 & Rough & L-Form & Irregular (erose) & Raised \\
\hline & 8 & 021 & 0.11071498 & Rough & Round & Entire (smooth) & Convex \\
\hline & 9 & 027 & 0.109940888 & Rough & Round & Entire (smooth) & Convex \\
\hline & 10 & 029 & 0.103462368 & Rough & Round & Entire (smooth) & Umbonate \\
\hline & 11 & 032 & 0.102946238 & Rough & Wrinkled & Wavy (undulate) & Hilly \\
\hline & 12 & A66 & 0.101023699 & Rough & Round & Entire (smooth) & Convex \\
\hline & 13 & A54 & 0.10029139 & Rough & L-form & Wavy (undulate) & Umbonate \\
\hline & 14 & A100 & 0.100184044 & Rough & Round & Entire (smooth) & Convex \\
\hline & 15 & A14 & 0.099408266 & Rough & Round & Entire (smooth) & Convex \\
\hline & 16 & A72 & 0.096973307 & Rough & Wrinkled & Lobate & Hilly \\
\hline & 17 & 048 & 0.094574547 & Rough & Round & Entire (smooth) & Umbonate \\
\hline & 18 & A7 & 0.094520668 & Rough & Wrinkled & Lobate & Hilly \\
\hline & 19 & A94 & 0.091146119 & Rough & L-form & Wavy (undulate) & Umbonate \\
\hline & 20 & 043 & 0.08869095 & Rough & Irregular and spreading & Lobate & Hilly \\
\hline & 21 & A99 & 0.088012125 & Rough & L-form & Wavy (undulate) & Umbonate \\
\hline & 22 & 019 & 0.085249413 & Rough & Round & Entire (smooth) & Umbonate \\
\hline & 23 & $\mathrm{~A} 10$ & 0.080900967 & Rough & L-form & Wavy (undulate) & Umbonate \\
\hline \multirow[t]{25}{*}{ Gram (+) } & 24 & 053 & 0.078370769 & Rough & Wrinkled & Lobate & Hilly \\
\hline & 25 & 022 & 0.077797327 & Rough & Wrinkled & Lobate & Hilly \\
\hline & 26 & A97 & 0.077129204 & Rough & L-form & Irregular (erose) & Umbonate \\
\hline & 27 & 028 & 0.076418403 & Smooth and glistening & Round & Entire (smooth) & Convex \\
\hline & 28 & A59 & 0.074083112 & Rough & Wrinkled & Wavy (undulate) & Hilly \\
\hline & 29 & A95 & 0.071900556 & Rough & L-form & Wavy (undulate) & Umbonate \\
\hline & 30 & A98 & 0.06687196 & Rough & Wrinkled & Lobate & Hilly \\
\hline & 31 & 09 & 0.063265297 & Rough & Round & Wavy (undulate) & Flat \\
\hline & 32 & 051 & 0.061335253 & Rough & Round & Entire (smooth) & Convex \\
\hline & 33 & 059 & 0.060855181 & Rough & Round & Wavy (undulate) & Flat \\
\hline & 34 & A20 & 0.055303673 & Rough & L-form & Wavy (undulate) & Umbonate \\
\hline & 35 & 056 & 0.053742364 & Rough & L-form & Wavy (undulate) & Umbonate \\
\hline & 36 & A48 & 0.051017101 & Rough & Round & Entire (smooth) & Convex \\
\hline & 37 & A101 & 0.050060666 & Rough & L-form & Wavy (undulate) & Raised \\
\hline & 38 & 035 & 0.048140823 & Rough & Round & Wavy (undulate) & Flat \\
\hline & 39 & 042 & 0.047199334 & Rough & Round & Entire (smooth) & Convex \\
\hline & 40 & 011 & 0.046469919 & Rough & Round with scalloped margin & Entire (smooth) & Umbonate \\
\hline & 41 & 031 & 0.045693047 & Rough & Wrinkled & Lobate & Hilly \\
\hline & 42 & A16 & 0.043665948 & Rough & Wrinkled & Lobate & Hilly \\
\hline & 43 & A22 & 0.042588727 & Rough & L-form & Wavy (undulate) & Umbonate \\
\hline & 44 & 061 & 0.03825781 & Rough & Round & Entire (smooth) & Umbonate \\
\hline & 45 & A64 & 0.032601126 & Rough & L-form & Wavy (undulate) & Umbonate \\
\hline & 46 & 016 & 0.029383064 & Rough & Round & Entire (smooth) & Umbonate \\
\hline & 47 & A51 & 0.020904739 & Rough & Wrinkled & Entire (smooth) & Hilly \\
\hline & 1 & A102 & 0.097315067 & Smooth and glistening & Wrinkled & Wavy (undulate) & Umbonate \\
\hline \multirow{3}{*}{ Gram (-) } & 3 & A27 & 0.073022516 & Smooth and glistening & Wrinkled & Wavy (undulate) & Drop-like \\
\hline & 4 & A67 ॥ & 0.061267755 & Smooth and glistening & Wrinkled & Wavy (undulate) & Drop-like \\
\hline & 5 & A67I & 0.051438901 & Smooth and glistening & Round with raised margin & Wavy (undulate) & Drop-like \\
\hline
\end{tabular}


Dari hasil pengamatan bentuk sel diketahui seluruh isolat berbentuk batang. Hasil pengecatan Gram menunjukkan 47 isolat adalah Gram positif dan sisanya 4 isolat adalah Gram negatif. Fakta yang menarik adalah seluruh isolat dari fase organik adalah bakteri Gram positif, sedangkan dari fase air sebanyak 25 isolat adalah Gram positif dan sisanya 4 isolat adalah bakteri Gram negatif. Pada perhitungan kinetika pertumbuhan diketahui laju pertumbuhan spesifik $(\mu)$ setiap isolat berkisar antara 0,02 / jam - 0,16 / jam. Pengamatan morfologi koloni sangat bervariasi akan tetapi untuk permukaan koloni $90 \%$-nya adalah rough. Hal ini menunjukkan bahwa jumlah bakteri Gram positif yang toleran terhadap uranium pada konsentrasi $2 \mathrm{mM}$ lebih banyak dari pada jumlah bakteri Gram negatif. Meskipun demikian, sifat toleran / resisten terhadap uranium ini nampaknya tidak berkaitan dengan sifat Gram suatu bakteri karena pada berbagai penelitian ditemukan juga strain bakteri Gram negatif yang toleran terhadap uranium seperti Pseudomonas, Acinetobacter, Escherichia coli dan Citrobacter. Sifat resistensi ini berkorelasi dengan kapasitas luar biasa bakteri tersebut dalam memperbaiki kerusakan hebat yang terjadi pada DNA bakteri tersebut [22].

\section{Pengelompokan Isolat Bakteri Toleran Uranium denganTeknik Rep-PCR}

Kemungkinan bahwa 51 isolat bakteri toleran uranium ini memiliki tingkat kemiripan tinggi atau identik dapat disidik dengan teknik rep-PCR. Dengan teknik rep-PCR dapat dilakukan seleksi strain bakteri yang digunakan dalam pengujian selanjutnya [23]. Dendrogram hasil analisis sidik jari genom DNA seluruh 51 isolat bakteri dengan rep-PCR ditunjukkan pada Gambar 1.

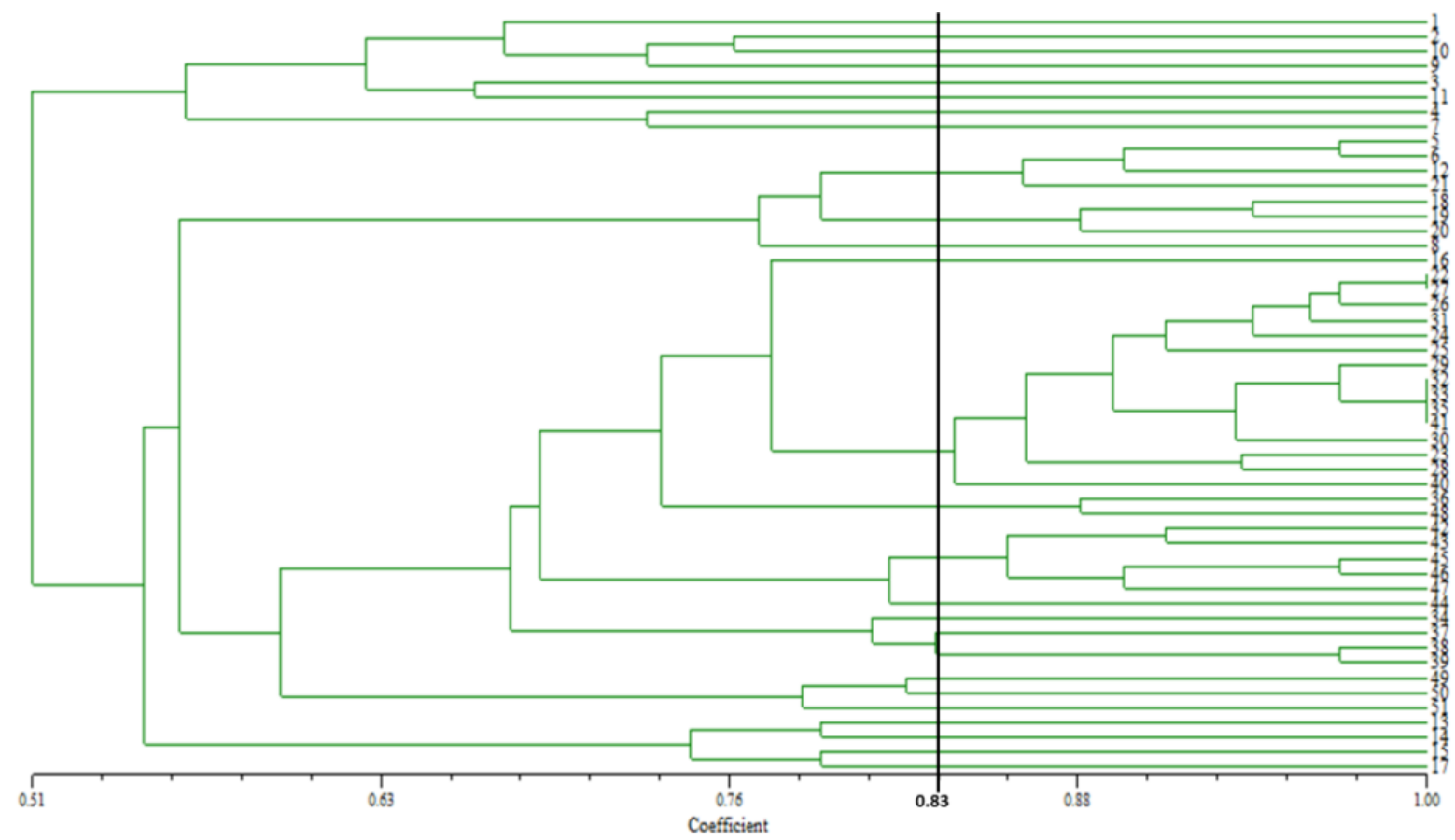

Gambar 1. Dendrogram yang menunjukkan keserupaan 51 isolat bakteri toleran uranium dengan rep-PCR

Berdasarkan dendrogram ini nampak jelas bahwa tingkat homogenitas genetik 51 isolat bakteri ini relatif rendah. Sebaran klaster bakteri terdapat merata dengan keserupaan sekitar $50 \%-90 \%$. Selain dengan menganalisis dan menetapkan tingkat homogenesitas genetik yang relatif homogen agar dapat dilakukan seleksi isolat bakteri dengan metode rep-PCR juga dikombinasikan dengan karakter morfologi koloni isolat bakteri. Berdasarkan metode ini diperoleh 26 klaster dari 51 isolat bakteri toleran uranium pada tingkat kesamaan $83 \%$.

\section{Seleksi bakteri polifosfat}

Setelah diperoleh 26 klaster isolat bakteri toleran uranium berdasarkan tingkat keserupaan $83 \%$ dengan rep-PCR, selanjutnya dipilih satu isolat dari masing-masing klaster yang mempunyai kecepatan pertumbuhan 
spesifik $(\mu)$ tertinggi. Diperoleh 26 isolat bakteri toleran uranium yang kemudian diseleksi untuk mendapatkan bakteri polifosfat dalam medium agar yang tidak mengandung $P$ dan diinkubasikan selama 5 hari pada suhu ruang untuk diamati daya hidupnya [19]. Berdasarkan atas hasil seleksi ini diperoleh 7 isolat bakteri polifosfat yang mampu tumbuh dalam medium tersebut. Bakteri polifosfat ini diberi kode sebagai berikut : A-14; A-35; A-66; A-67 I; 0-21; 0-27; dan 0-29. Isolat A-67 I bersifat Gram negatif berbentuk batang, sedangkan ke 6 isolat yang lain bersifat Gram positif berbentuk batang (Gambar. 2). Berdasarkan atas hasil skrining ini maka ke 7 isolat ini ditetapkan sebagai bakteri polifosfat yang digunakan dalam eksperimen selanjutnya. Bakteri polifosfat ini mampu menghasilkan energi dari cadangan polifosfat yang disimpan di dalam selnya sehingga bakteri tetap mampu tumbuh [24].

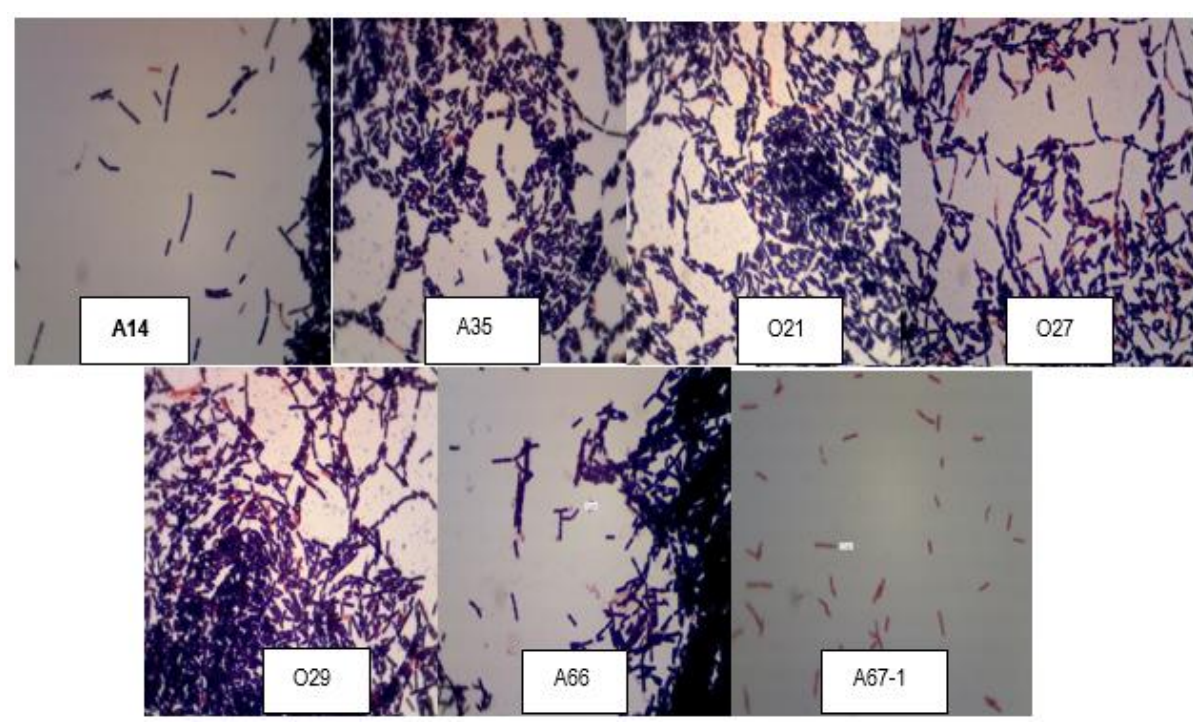

Gambar 2. Hasil pengecatan Gram bakteri polifosfat yang diamati dengan mikroskop cahaya dengan perbesaran $100 \times$ 15. Isolat bakteri A14, A35, O21, O27, O29, dan A66 berbentuk batang berwarna ungu (Gram positif) sedangkan isolat $A 67-1$ berbentuk batang berwarna merah (Gram negatif)

\section{Analisis filogenetik}

Gen 16S rRNA merupakan gen yang bersifat lestari (conserved) yang terdapat pada semua bakteri dan dapat digunakan untuk mengklasifikasikan bakteri berdasarkan atas hubungan kekerabatannya. Hasil analisis hubungan filogenetik berdasarkan urutan nukleotida gen 16S rRNA ditunjukkan pada Gambar 3. Hubungan filogenetik 7 isolat bakteri polifosfat dengan 2 isolat bakteri acuan yaitu Bacillus cereus ATCC 14579 dan Acinetobacter radioresisten DSM 6976, terbagi menjadi 2 clade.

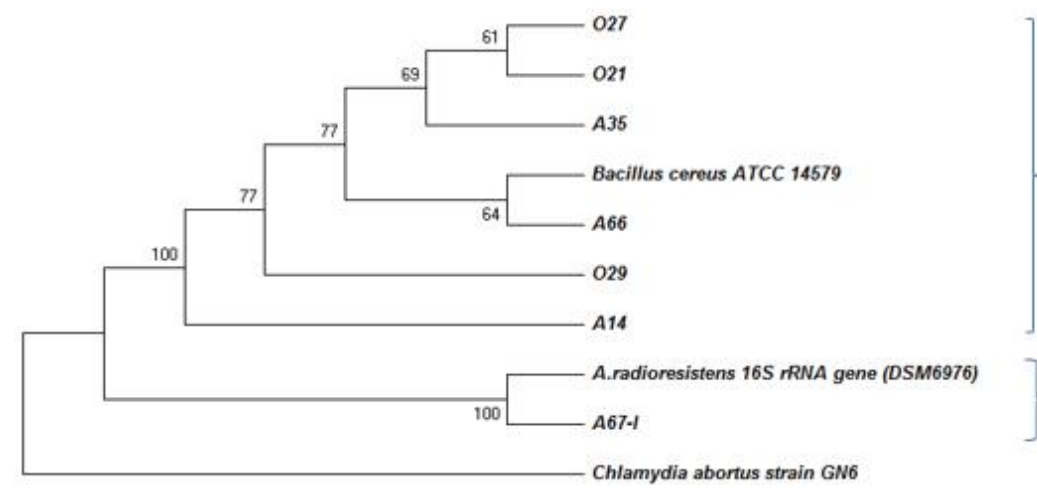

Clade-1

Clade-2

Gambar 3. Pohon filogeni yang menunjukkan hubungan kekerabatan antara 7 isolat bakteri polifosfat atas dasar sekuen gen $16 \mathrm{~S}$ rRNA dengan 2 isolat bakteri sebagai acuan 
Clade pertama terdiri atas 6 isolat bakteri polifosfat gram positif bentuk batang (A14, O29, 021, 027, A35, dan A66) dengan strain acuan yaitu Bacillus cereus ATCC14579. Nilai keserupaan 6 isolat tersebut dengan Bacillus cereus ATCC 14579 sebesar 97,64 - 99,93\%, dengan perbedaan nukleotida 1- 34 nukleotida, ditunjukkan padaTabel 4. Berdasarkan atas nilai keserupaan dan perbedaan nukleotida maka 6 isolat bakteri polifosfat ini memiliki kemiripan dengan bakteri acuan Bacillus cereus.

Tabel 4. Matriks keserupaan dan perbedaan nukleotida gen 16S rRNA 6 isolat bakteri polifosfat dengan strain acuan Bacillus cereus ATCC 14579

\begin{tabular}{llllllll}
\hline & $\begin{array}{l}\text { Bacillus cereus } \\
\text { ATCC 14579 }\end{array}$ & A35 & O27 & O29 & 021 & A14 & A66 \\
\hline $\begin{array}{l}\text { Bacillus cereus } \\
\text { ATCC 14579 }\end{array}$ & & 99,44483 & 99,72241 & 97,64053 & 99,9306 & 98,82026 & 98,51169 \\
A35 & $8 / 1441$ & & & & & & \\
O27 & $4 / 1441$ & $10 / 1441$ & 99,30604 & 97,22415 & 99,51423 & 98,40389 & 98,61207 \\
O29 & $34 / 1441$ & $40 / 1441$ & $36 / 1441$ & 97,50173 & 99,79181 & 98,68147 & 97,08536 \\
O21 & $1 / 1441$ & $7 / 1441$ & $3 / 1441$ & $33 / 1441$ & 97,70992 & 96,5998 & 98,68147 \\
A14 & $17 / 1441$ & $23 / 1441$ & $19 / 1441$ & $49 / 1441$ & $16 / 1441$ & 98,88966 & 98,33449 \\
A66 & $21 / 1441$ & $20 / 1441$ & $42 / 1441$ & $19 / 1441$ & $24 / 1441$ & $19 / 1441$ & \\
\hline
\end{tabular}

Clade kedua terdiri atas satu isolat bakteri polifosfat gram negatif bentuk batang (A 67-I) dan satu strain acuan Acinetobacter radioresisten DSM 6976. Nilai keserupaan keduanya adalah 99,06 \% dengan perbedaan jumlah nukleotida sebanyak 13 yang ditunjukkan olehTabel 5 . Berdasarkan atas nilai keserupaan nukleotida maka isolat A 67-I mempunyai kemiripan dengan bakteri acuan Acinetobacter radioresisten.

Tabel 5. Matriks keserupaan dan perbedaan nukleotida sekuen gen 16S rRNA isolat bakteri A67-I dengan strain acuan Acinetobacter radioresisten.

\begin{tabular}{lcc}
\hline & Acinetobacter radioresisten (DSM 6976) & A 67-I \\
\hline Acinetobacter radioresisten (DSM 6976) & $13 / 1389$ & 99.0640749 \\
A 67-I & & \\
\hline
\end{tabular}

\section{KESIMPULAN}

Dari hasil isolasi dan skrining limbah radioaktif cair aktivitas rendah PSTA BATAN Yogyakarta berhasil didapatkan 51 isolat bakteri toleran uranium sampai pada konsentrasi $2 \mathrm{mM}$. Diantara 51 isolat bakteri ini ada 7 isolat yang merupakan bakteri polifosfat yang berpotensi dalam biopresipitasi uranium. Berdasarkan hasil analisis sekuen gen 16S rRNA, 5 isolat bakteri polifosfat (A14, A66, A35, 027, O21 dan 029) diketahui memiliki kemiripan dengan Bacillus cereus, sedangkan isolat bakteri polifosfat dengan kode A 67-I memiliki kemiripan dengan Acinetobacter radioresisten.

\section{DAFTAR PUSTAKA}

[1] P. Kumar - Jain, S. Ramachandran, V. Shukla, D. Bhakuni and S.K. Verma, International Journal of Integrative Biology,Vol. 6, No. 2, 2009.

[2] T. Borch, R. Kretzschmar, A. Kappler, P.V. Capeller, M. Ginder-Vogel, A.Voegelin, K. Campbell, Environ. Sci. Technol, Vol. 44, pp. 15-23, 2010.

[3] M.F. Abdel-Sabour. Electronic Journal of Environmental Agricultural And Food Chemistry 6, Vol. 5, pp. 2009-2023, 2007. 
[4] M.I. Merrour. "In Applied Microbiology", A.Mendez-Villas, pp. 108-119, 2007.

[5] P.T. Todorov and E.N. Illieva, Rom. Journ. Phys., Vol. 51, Nos. 1-2, pp. 27- 34, 2006.

[6] L. Zavodska, E. Kosorinova, L. Scerbakova, and J. Lesny, HUISSN 1418-7108: HEJ Manuscript, No : ENV-081221-A, 2009.

[7] M. Gavrilescu, Eng. Life Sci, Wiley-vch Verlag Gmbh \& Co.KGaA, Weinheim, Vol.4, No.3, 2004.

[8] N. Renninger, K.D. McMahon, R. Knopp, H. Nitsche, D.S. Clark, and J.D. Keasling. Biodegradation,Vol. 12, pp. $401-410,2001$.

[9] R.A.I. Abou-Shanab, "Biomanagement of Metal-contaminated Soils", Environmental Pollution 20, in M. S. Khan, et al., Springer Science + Bussiness Media. B.V, 2011.

[10] D. Appukuttan, A.S. Rao, and S.K. Apte.,Appl.Environ. Microbiol, Vol. 72, pp. 7873-7878, 2006.

[11] L.E. Macaskie, K.M. Bonthrone, P. Yong, and D.I. Goddard., "In Biomineral Formation”, Microbiology, Vol. 146, , pp.1855-1867, 2000.

[12] M.J. Beazly, R.J. Martinez, P.A. Sobecky, S.M. Webb, and M. Taillefert. "In Sights From Bacterialisolats From A Contaminated Sub Surface Environ", SCI.Technol, Vol. 41, pp. 5701-5707, 2007.

[13] R.J. Martinez, M.J. Beazly, M. Taillefert, A.K. Arakaki, J. Skolnick, and P.A. Sobecky, Environ.Microbiol, Vol. 9, pp. 3122-3133, 2007.

[14] N. Renninger, R. Knopp, H. Nitsche, D.S. Clark, and J.D. Keasling, Appl. Environ. Microbiol, Vol. 70, pp. 7404-7412, 2004.

[15] E.S. Shelobolina, S.A. Sullivar, K.R. O'Neill, K.P. Nevin, and D.R. Lovley, Appl. Environ. Microbial, Vol. 70, pp. 2959-2965, 2004.

[16] K.S. Nilgiriwala, A. Alahari, A.S. Rao, and S.K. Apte., Appl. Environ. Microbial, Vol. 74, pp. 5516-5523, 2008,

[17] E. Rustrian, J.P. Delgenes, and R. Moletta., Letters in Applied Microbiology, Vol. 24, pp. 144-148,1997.

[18] J.L.W. Rademaker, N.J.M. Aarts, and P. Vinuesa, In Molecular Microbial Ecology, (Osborn, A.M and Smith, C.J, Eds), Taylor \& Francis Group, 2005.

[19] J.A. Gavigan, L.M. Marshall, and A.D.W. Dobson, Microbiology, Vol. 145, pp. 2931-2937, 1999.

[20] F.M. Ausubel, R. Brent, R.E. Kingston, D.D. Moore, J.G. Seidman, J.A. Smith and K. Struhl. "In Molecular Biology", John Willey \& Sons, Inc., USA, Vol.1, 1997.

[21] D. Lane, In : Stackebrandt E., Goodfellow, M (eds). "Nucleic Acid Techniques in Bacterial Systematics", Wiley, United Kingdom, pp 115-175, 1991.

[22] A. Kristo and M. Radman, In Friedberg, E.C. et al. (Eds). "DNA Repair, Mutagenesis, and Other Responses to DNA Damage", Cold Spring Harb Respect Biol, Vol. 5, No. a012765, 2013.

[23] A. Lisek, L. Sas Paszt, M. Oskiera, P. Trzcinski, A. Bogumil, A. Kulisiewicz, and E. Malusa. Journal of Fruit and Ornamental Plant Research, Vol 19, No. 1, pp. 5-12, 2011.

[24] R.J. Seviour, T. Mino, and M. Onuki. "In Activated Sludge Systems", FEMS Microbiol Rev, Vol. 27, No. 1, pp. 99-127, 2003. 